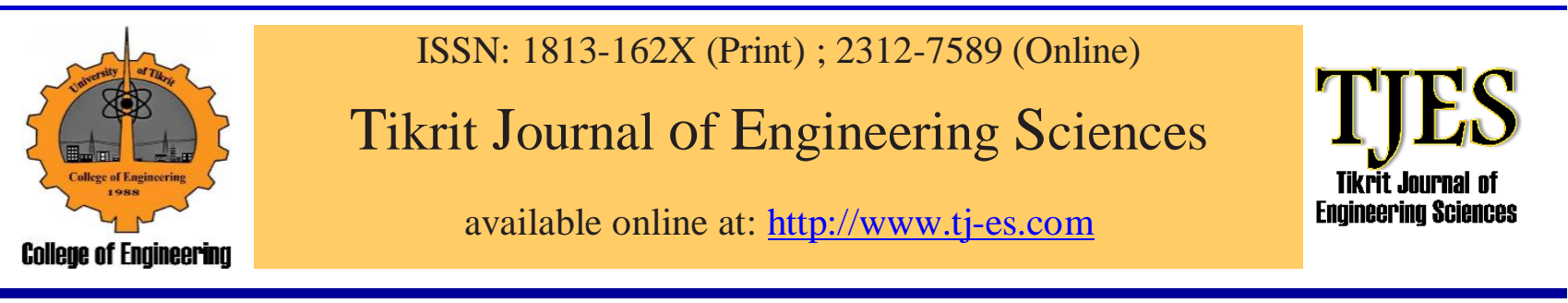

Al-Luhybi AS. Mechanical properties of recycled aggregate concrete with steel fiber: A review.. Tikrit Journal of Engineering Sciences 2019; 26(3): 37-42.

\section{Ashtar S. Al-Luhybi*}

Civil Department, Engineering

College, Mosul University

Mosul, Iraq

\section{Keywords:}

Preserving the Environment Coarse recycled aggregate Recycled Aggregate Concrete Steel Fiber

Mechanical Properties

\section{A R T I C L E I N F O}

\section{Article history:}

Received 15 Sep. 2019

Accepted 20 Dec. 2019

Available online 27 Dec. 2019

\title{
MECHANICAL PROPERTIES OF RECYCLED AGGREGATE CONCRETE WITH STEEL FIBER: A REVIEW
}

\begin{abstract}
A B S T R A C T
In the building process, the recycling of aggregates arising from building and demolition debris is one of the best alternatives to maintain the environment and the areas needed to bury these debris. It also helps to preserve natural concrete sources from depletion efficiently. The use of recycled aggregates in new concrete manufacturing, however, leads to a decrease in concrete's strength characteristics. This reduction rises with the rise in the percentage of recycled aggregates used in concrete, which has caused many researchers to undertake many researches on how to enhance the characteristics of recycled aggregate-containing concrete. This paper presents several studies that examined the effect of adding steel fiber to improve the properties of concrete containing a coarse recycled aggregate.
\end{abstract}

() 2019 TJES, College of Engineering, Tikrit University

\section{الخواص الميكاتيكية للخرسانة الحاوية على ركام معاد مع الألياف الفولاذية: مراجعة عشتار صالح اللهيبي/ قسم الهندسة المدنية، كلية هندسة ، جامعة الموصل الخلاصة}

ان إعادة استخدام الركام الناتج من مخلفات البناء و الهدم في عملية البناء مرة ثانية هي من افضل الحلول التي تم اتباعها للحفاظ على البيئة

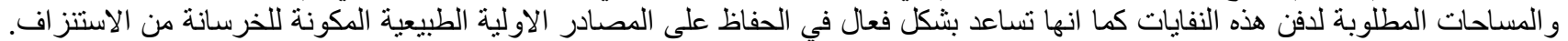

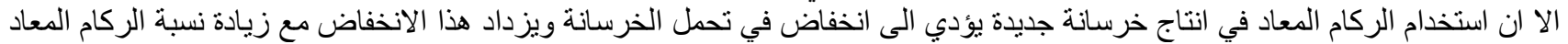

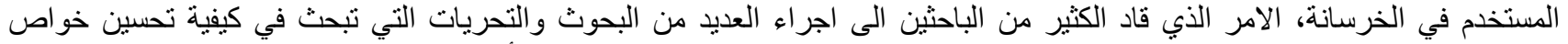

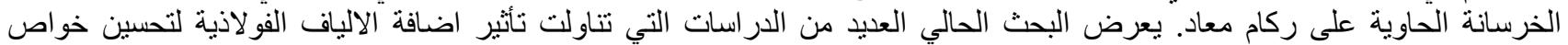
الخرسانة الحاوية على ركام خشن معاد معاد.

الكلمات الدالة: حماية البيئة، ركام خشن معاد، ركام كونكريت معاد، خصائص ميكانيكية.

* Corresponding Author: E-mail: aziztaher@uomosul.edu.iq

\section{Introduction}

Because of its low cost and material accessibility, concrete is presently one of the most commonly used construction products in all over the world [1]. There are more reasons why concrete is a very commonly used material in construction. In case it has been designed and produced in an appropriate manner, it will have great mechanical properties and durability. Concrete is characterized by its ability to take any form or mold, adaptable, relatively fire resistant, available at reasonable prices [2]. Its maintenance costs are low, easy to handle, good at carrying compression. For these purposes, in the building industry, concrete is the most appropriate material [3]. Around the world, concrete is produced at more than 10 billion tons per year, to prepare 10 billion tons of concrete, 10 billion tons of concrete materials are needed [4]. This means that the concrete industry 
consumes and drains large amounts of natural resources and therefore causes environmental, economic and energy losses [5].It was also found that the total quantities of construction and demolition debris around the world is estimated to be (2-3) billion per year [6].Singh and Sharma [7] mentioned some of the reasons that increase the volume of construction debris:

- Many of the old buildings, concrete pavements and bridges are over-old; their use has become limited as a result of the deterioration it has suffered, which cannot be repaired and need to be demolished.

- Demolition of concrete structures that do not serve the current need.

- The need for new facilities for better economic growth.

- The constructions collapse and turn into debris when exposed to some natural disasters such as earthquakes, hurricanes and floods.

- Sometimes the debrisis produced by man-made wars.

These debris and their large quantities are either collected in the collection site of waste and accumulate annually and since they are durable, not biodegradable or decomposable, they occupy large areas of the earth $[8,9]$, or may be disposed of by burying them in landfills [10-12]. In both cases, it is another environmental problem.

Therefore, on the one side, natural resources are depleted and on the other, big amounts of building and demolition waste. Therefore, it was necessary to find a solution that reduces the depletion of natural resources and the exploitation of these wastes and reduce the amounts spent on burying and preserving the environment. One of the techniques used for recycling is the partial or total substitute of the ordinary aggregate in the manufacturing of fresh concrete. Where the concrete blocks that do not contain pieces of wood, reinforcement steel bars or gypsum products are broken into sizes similar to the size of the natural gravel and then washed and separated into certain sizes after sifting with sieves. Reusing debris is a cheap source of aggregate for non-gravel countries [13], this is in addition to solving the two previous environmental problems.

\section{Recycled aggregate concrete}

Recycled aggregate concrete can be defined as concrete containing the recycled (coarse or fine) aggregate arising from demolition and building debris as a complete or partial substitute of the natural aggregate [5]. Although the use of recycled aggregate from construction and demolition debris has solved two environmental problems, its use in the formation of new concrete negatively affects its mechanical properties. This is due to a major reason, which is the presence of the old cement mortar attached to the recycled aggregate, this mortar causes increased water absorption of the new concrete[14,15].The bulk density of the concrete, which contains a coarse recycled aggregate, is less than the normal concrete. This is also due to the cement paste on the surface of the recycled aggregates $[16,17]$. The modulus of elasticity of the concrete containing the recycled aggregate is reduced in value compared to the conventional concrete [18, 19].

Several studies have been conducted on the effect of the addition of recycled aggregates on the compressive strength of the concrete. The results varied, it was found that the compressive strength of the concrete containing the recycled aggregate from the construction and demolition debris is less than normal concrete [20-26]. Many researchers have demonstrated that the recycled aggregates from well-known and good-quality concrete give concrete with an equivalent compressive strength and sometimes higher than the compressive strength of natural concrete [27-29]. Although the findings differ, it is not always known whether the recycled aggregate is from good quality concrete or not. The effect of the use of recycled aggregates in concrete on tensile and flexural strength has been studied and investigated in numerous researches. It has been concluded that the use of recycled aggregates reduces tensile and flexural strength [30-33]. Since in the recycled aggregate concrete, the content of the cement paste is high, this results in dry shrinkage and creep values higher than normal concrete [34].

Based on the above, a lot of studies is being performed to enhance the characteristics of concrete containing recycled aggregate, one of these methods is what researchers did by treating the recycled aggregate before using it either by immersing it with special solutions [35], or through processing using polymer materials [36], or by making the recycled aggregate saturated by immersing it with water before adding it to the concrete mixture and this is to reduce the water absorption of the old cement paste [37]. Some researchers have improved the characteristics of concrete containing recycled aggregate using plasticizers, which reduce the amount of water added to the mixer to get good workability for the concrete [9]. There are also researchers who have worked to improve the properties of this type of concrete through the addition of pozzolan materials [38-40]. There are other studies that investigated the effect of adding pozzolan materials and steel fibers on the behavior of concrete containing recycled aggregates [41-42].

\section{Research importance}

Several studies have been conducted to determine the extent, to which construction and demolition debris can be used as a recycled aggregate in concrete, the results showed that they could be used. The effect of many variables and additives for this type of concrete was also studied to improve its properties. The current research aims to present the results of some studies that investigated the effect of adding steel fibers to the concrete containing a coarse recycled aggregate. The research was limited to the selection of researches that study the effect of adding steel fiber without the addition of any other materials and without the presence of steel reinforcement, in order to determine the effect of the addition of steel fiber on the mechanical properties of the concrete containing the 
recycled aggregate and to make the picture clear to the rest of the researchers.

\section{The influence of using steel fiber on the mechanical characteristics of the recycled aggregate concrete}

Bhikshma and Manipal (2012) [43] investigated the effect of the addition of steel fibers on mechanical characteristics compressive, tensile and flexural strength and the modulus of elasticity of the recycled aggregate concrete. The two researchers conducted a practical study in which two concrete mixtures were prepared with two different compressive strength (20 and $30 \mathrm{MPa}$ ), and for both mixtures steel fibers were added with two different aspect ratios (40 and 60). For each aspect ratio, the steel fibers were added with variable ratios $(0,0.5,1,1.5 \%)$. The results showed that the addition of steel fiber improved the mechanical properties of recycled aggregate concrete. Where they found that when adding the steel fibers by $(1.5 \%)$ there is an increase in compressive, tensile and flexural strength of the recycled aggregate concrete with grade 20 and for two aspect ratios (40 and 60) reached to (25$31 \%)$, (28-30\%) and (23-25\%) respectively. The increase in compressive, tensile and flexural strength when adding the same percentage of fiber to the recycled aggregate concrete with grade 30 and for two aspect ratios (40and60) reached to (28-22\%), (39-36\%) and $(29-26 \%)$ respectively. The results showed that there was an increase in the values of the modulus of elasticity and for both mixings.

Hameed (2013) [44] also studied the effect of adding steel fiber on the properties of the concrete containing recycled aggregate, the diameter of this fiber was $(0.3 \mathrm{~mm})$ and length $(2.3 \mathrm{~mm})$ where the researcher casted mixtures without recycled aggregate and without steel fibers and mixtures containing recycled aggregate and without steel fibers. Other mixtures containing recycled aggregate with different ratios ranging from $(0 \%)$ to $(100 \%)$ were also casted and with the increment of $(25 \%)$ as an alternative to the normal aggregate with the presence of steel fiber with ratio $(6 \%)$ of the total weight of concrete. The results showed that the steel fiber improved the mechanical properties of the recycled aggregate concrete compared to the recycled aggregate concrete and without using of steel fiber in terms of compressive strength, tensile strength and modulus of elasticity.

Sryh and Forth (2015) [45] conducted a practical study aimed at determining the effect of addition of steel fibers on compressive, tensile, flexural strength and the modulus of elasticity of the recycled aggregate concrete. Where the researchers casted 12 concrete mixtures .These were divided into three groups, the first group used only normal aggregates with a change in the ratio of steel fiber where four ratios were used $(0,0.5,1,1.5 \%)$, in the second and third group of mixtures, the recycled aggregates were used with (50and $100 \%$ ) as an alternative to the normal aggregate with the addition of steel fibers by four ratios $(0,0.5,1$, $1.5 \%)$. Based on the results of the tests, the researchers concluded that the use of recycled aggregates with $(50 \%)$ in the concrete resulted in a decrease in compressive, tensile, flexural strength and a decrease in the modulus of elasticity by $(5,15,10$ and 20\%) respectively. The use of recycled aggregates with $(100 \%)$ in concrete caused a decrease in compressive, tensile, flexural strength and modulus of elasticity values with percentage that reached to $(10,30,22$, $30 \%$ ) respectively. This is due to the presence of mortar attached to aggregates and the cutting of bricks and mud. As for the effect of adding fiber to the mixtures, they found that the use of fiber has improved the mechanical characteristics of all mixtures, the addition of steel fibers increased the compressive, tensile, flexural strength and increased the modulus of elasticity. The researchers also observed that the compressive strength of the standard cylinders was higher than that of the cubes. The reason for this is the direction of the fiber is relative to the load. In cylindrical specimens, the direction of the fibers is perpendicular to the direction of the loading, unlike that in the cubes which is parallel.

Krishna (2015) [46] investigated the effect of the addition of steel fibers on compressive and flexural strength of the recycled aggregate concrete where the researcher prepared concrete mixtures containing different percentages of recycled aggregates $(0,25,50$, $75,100 \%)$ as alternative to the normal aggregate. The researcher also added different percentages of steel fiber for each mixture $(0,1,1.5,2 \%)$. The results showed that the use of steel fibers increased the compressive and flexural strength of the recycled aggregate concrete for all the ratios of replacement and for all added fiber ratios. The researcher also noted that the relationship of (load-deflection) of the beams were not affected when recycled aggregates are used with steel fiber when compared to beams containing natural aggregate.

Pradeep and Gowda (2016) [47] studied the effect of the use of steel fibers of the mesh type on the compressive and flexural strength of the recycled aggregate concrete. Where the researchers prepared concrete mixtures with variable content of recycled aggregates as an alternative to natural aggregates $(0$, $10,20,30 \%)$. For each content three variable ratios of fiber were added $(0,5$, and $10 \%)$ of the total volume of the mixture. The results showed that the addition of steel fibers improved the compressive strength where the increase was from (11 to $24 \%$ ) with the presence of recycled aggregates. They also noted that the absorption capacity of the beams prepared from recycled aggregate concrete and steel fibers which is calculated from the measurement of the area under the (load-deflection) curves of the beams is about 10-40 times higher than the normal mixtures.

Chandar et al. (2017) [48] investigated the effect of adding steel fibers to concrete with the presence of recycled aggregates, where they casted specimens of mixtures containing neither recycled aggregate nor steel fiber as control specimens and they also casted other mixtures containing recycled aggregate with ratio $(100 \%)$ as an alternative to the normal aggregate with the addition of steel fibers by five ratios $(0,0.5,1$, 
$1.5,2 \%)$. The results showed that the compressive strength of the recycled aggregate concrete was decreased by $(2.36 \%)$ but it is increased with the addition of steel fiber, the increase in compressive strength when adding steel fibers by $(1 \%)$ reached to $(10 \%)$. The addition of steel fibers improved the tensile strength of the recycled aggregate concrete and the increase is evident at the addition ratios ( 1 and $1.5 \%$ ).

Bhan and Kaur (2018) [49] investigated the effect of the addition of steel fibers on the mechanical properties of concrete containing recycled aggregate, which include compressive, tensile and flexural strength. Where the researchers studied the effect of changing the ratio of replacement of normal aggregates with recycled aggregates and the effect of changing the ratio of steel fibers on mechanical properties. Nine concrete mixtures were caste, three of which had the percentage of recycled aggregate $(0 \%)$, the variable was the ratio of steel fiber, three ratios were adopted in this study $(0,0.5$, and $1 \%)$, and the rest of the mixtures were divided into two groups. The variables in these two groups were the percentage of recycled aggregates where two ratios (50 and 100\%) were added as an alternative to normal aggregates and the content of steel fibers where three different ratios were used $(0$, $0.5,1 \%)$, after testing the specimens, the researchers noted that there is a decrease in compressive, tensile and flexural strength of the concrete with increased percentage of recycled aggregates. They also found that the use of steel fiber enhanced the compressive, tensile and flexural strength and it increased by increasing the proportion of steel fiber.

Sryh and Forth (2016) [50] investigated the effect of adding steel fibers on dry shrinkage and creep of the recycled aggregate concrete. Where the researchers prepared nine concrete mixtures divided into groups where the variables in the mixtures were the percentage of recycled aggregates, for which they used three ratios $(0,50$ and $100 \%)$ as substitutes for normal aggregates. They also used three ratios of steel fiber $(0,0.5$, and $1 \%)$. The results showed that by increasing the proportion of recycled aggregates, dry shrinkage increases and the values of compressive creep and tensile creep increase, but they found that the addition of steel fibers to the recycled aggregate concrete reduced the percentage of increase in the values of dry shrinkage, compressive and tensile creep by ratio reaching to $(15,5$ and $20 \%)$ respectively, with the addition of $(1 \%)$ of steel fiber. They also noticed that the effect of steel fiber is evident on the tensile creep rather than the compressive creep.

Ghorpade (2013) [51] studied the effect of adding steel fibers on shear strength of high strength concrete containing recycled aggregate where the researcher prepared concrete mixtures containing recycled aggregate with different ratios $(0,20,40,60,80,100 \%)$ and for each mix of these mixtures added two ratios of steel fiber $(0.1 \%)$. The results showed that when the percentage of recycled aggregate was increased, shear strength was reduced but the addition of steel fiber improved and increased the shear strength. The researcher recommended that it is desirable for considerations of shear strength that the replacement of natural aggregates with recycled aggregates should be up to $20 \%$.

Heeralal et al. (2009) [52] studied the effect of fatigue behavior of concrete beams containing recycled aggregate and steel fibers. The researchers carried out their study on standard beams of dimensions $(100 \times$ $100 \times 450 \mathrm{~mm}$ ), which were examined under static load and fatigue load. Variables in this study were the percentage of recycled aggregates, where the recycled aggregates were used $(0,50,100 \%)$, the ratio of steel fibers was $1 \%$ by volume. The results showed that with the increase in the percentage of recycled aggregate, the flexural strength of the beams decreased but increased by $(15 \%)$ when adding the steel fiber. The researchers also noted that the number of loading cycles decreases with the increase of the percentage of recycled aggregate but it increases with the addition of steel fiber and failure is slow. The results showed that the absorption capacity of the beams containing recycled aggregate and steel fiber is higher than the beams without fiber. The results also showed that the maximum deflection at ultimate static load and maximum deflection at fatigue test of the beams were close for the same type of beam.

\section{Conclusion}

Based on the results of the studies, the following can be concluded:

1- Increasing the proportion of coarse recycled aggregate in the concrete mix negatively impacts the concrete's mechanical characteristics.

2- The use of steel fibers in the recycled aggregate concrete increases the compressive, tensile, flexural and shear strength, and works to increase the modulus of elasticity.

3- The use of steel fibers reduces the dry shrinkage and creep of the recycled aggregate concrete.

4- Steel fiber use increases the absorption ability of the beams containing a recycled aggregate.

\section{References}

[1] Paul S C. Mechanical "Behaviour and Durability Performance of Concrete Containing Recycled Concrete Aggregate". M.Sc. Thesis: The University of Stellenbosch; South Africa: 2011.

[2] Meyer C. "The Greening of the Concrete Industry". Cement \& Concrete Composites 2009; 31: 601-605.

[3] Akbari Y V, Arora N K, Vakil M D. "Effect on Recycled Aggregate on Concrete Properties". International Journal of Earth Sciences and Engineering 2011; 4(6): 924-928.

[4] Meyer C. "The Greening of the Concrete Industry". The 2013 world congress on advances in structural engineering and mechanics. 2013, September8-12; jeju, korea: pp.79-92.

[5] Lalramsanga, Hmar L. "Study of Partial Replacement of Natural Aggregate by Recycled Aggregate on Concrete". International Journal of 
Latest Engineering and Management Research 2017; 2(11):1-6.

[6] Mohammed T U. "Sustainable Development of Concrete Technology ". Proceedings of the CBMCI International Workshop 2007. Karachi, Pakistan: pp.249-267.

[7] Internet Source: Sharma PC, Singh SK. Use of Recycled Aggregate in Concrete-A Paradigm Shift. http://www.nbmcw.com. (Retrieved 2009)

[8] Al-Qatan M T, Kasim E A, Al-Khatib H E. "Use of Construction Waste in Concrete Mixes". $A L$ Taqani 2012; 25(3): 20-27.(In Arabic).

[9] Hawi K H. "Influence of Superplasticizer on Recycled Coarse Aggregate Concrete". Journal of Kerbala University 2014; 12(4):11-24 (In Arabic).

[10] Malešev M, Radonjanin V, Marinković S. "Recycled Concrete as Aggregate for Structural Concrete Production". Sustainability 2010; 2: 1204-1225.

[11] Dabhade A N, Choudhari S R, Gajbhiye A R. "Performance Evaluation of Recycled Aggregate Used in Concrete". International Journal of Engineering Research and Applications 2012; 2(4): 1387-1391

[12] Ramadevi K, Chitra R. "Concrete Using Recycled Aggregates". International Journal of Civil Engineering and Technology 2017; 8 (9): 413-419.

[13] AL-Bukhaiti K, Hassan M, Hamzah A, Zaidi K, Ali A. "Study the Recycling and Use of Construction Waste in Concrete Mixtures in Yemen". International Journal of Scientific \& Engineering Research 2018; 9(3):1152-1154.

[14] Rahal K. "Mechanical Properties of Concrete with Recycled Coarse Aggregate". Building and Environment 2007; 42: 407-415.

[15] Tam V W, Tam C M, Le K N. "Removal of Cement Mortar Remains from Recycled Aggregate Using Pre-Soaking Approaches". Resources Conservation and Recycling 2007; 50: 82-101.

[16] Malešev M, Radonjanin V, Broćeta G. "Properties of Recycled Aggregate Concrete". Contemporary Materials 2014; 2: 239-249.

[17] Kumar S, Pal S, Kisku N, Pandey V. "Experimental Investigation of Recycled Aggregate Concrete Using Pre-Soaked Slurry Two Stage Mixing Approach". International Journal of Civil Engineering and Technology 2017; 8(1): 89-97.

[18] Vyas C M, Bhatt D R. "Evaluation of Modulus of Elasticity for Recycled Coarse Aggregate Concrete". International Journal of Engineering Science and Innovative Technology 2013; 2(1): 26-29.

[19] Karim Y, Khan Z, Alsoufi M S, Yunus M. "A Review on Recycled Aggregates for the Construction Industry". American Journal of Civil Engineering and Architecture 2016; 4(1): 32-38.

[20] Alzouhayli K, Mokbel T. "Experimental Study on the Recycled Aggregate Concrete". Tishreen University Journal for Research and Scientific
Studies- Engineering Sciences Series 2014; 36(2): 253-266.(In Arabic)

[21] Adnan S H, Loon L Y, Abdul Rahman I, Saman H M, Soejoso M W. "Compressive Strength of Recycled Aggregate Concrete with Various Percentage of Recycled Aggregate". Conference National Seminar on Civil Engineering Research (SEPKA 2007) December11-12; Skuda, Malaysia: UniversitiTeknologi: 11p.

[22] Fumoto T, Yamada M. "Strength and Drying Shrinkage of Concrete Used Recycled Aggregate". Mem. Fac. Eng., Osaka City Univ. 2003; 44: $79-82$.

[23] Uche O A U. "Influence of Recycled Concrete Aggregate (RCA) on Compressive Strength of Plain Concrete". Continental J. Engineering Sciences 2008; 3: 30-36.

[24] Topçu İ B, Şengel S. "Properties of Concretes Produced with Waste Concrete Aggregate". Cement and Concrete Research 2004; 34: 13071312

[25] Salehlamein F R, Solikin M, Sri Sunarjono I. "Effect of Recycled Coarse Aggregate on Concrete Properties". International Journal of Innovative Research in Science Engineering and Technology 2015; 4 (1):19060-19068.

[26] Al-Sulayfani B J, Aljubory N H, Al-Luhybi A S. "Design Chart of Concrete Containing Recycled Coarse Aggregate". Al-Rafidain Engineering 2011; 19(5): pp. 1-9.

[27] AL-Luhybi A S. "Studying the Effect of Adding Marble and Porcelain Waste on Mechanical Properies of Concrete Containing Recycled Aggregate". Engineering and Technology Journal 2017; 35: 668-674.

[28] Yong P C, Teo D C L "Utilisation of Recycled Aggregate as Coarse Aggregate in Concrete". UNIMAS E-Journal of Civil Engineering 2009; 1(1): 1-6.

[29] Duan Z H, Poon C S. "Properties of Recycled Aggregate Concrete Made with Recycled Aggregates with Different Amounts of Old Adhered Mortars". Materials and Design 2014; 58:1-24

[30] Qureshi L A, Munir M J, Mubeen T, Tasaddiq R M. "Effect of Using Recycled Concrete as Coarse Aggregate on Tensile and Flexural Strength of Concrete " 4th International Conference on Sustainable Construction Materials and Technologies. 2016, August 7-11; Las Vegas, USA.

[31] Sharma J, Singla S. "Influence of Recycled Concrete Aggregates on Strength Parameters of Concrete. SSRG International Journal of Civil Engineering" 2014; 1(4): 20-24.

[32] Ahmed M D S, Vidyadhara H S. "Experimental Study on Strength Behaviour of Recycled Aggregate Concrete". International Journal of Engineering Research \& Technology 2013; 2(10):76-82.

[33] Gangaram S, Bhikshma V, Janardhana M. "Development of M20 and M30 Grade of Recycled Aggregate Concrete by Replacing 100\% 
Virgin Aggregates with Recycled Aggregates". International Journal of Advance Engineering and Research Development 2018; 5 (3): 203-209.

[34] Anderson K W, Uhlmeyer J S, Russell M. "Use of Recycled Concrete Aggregate in PCCP: Literature Search". WSDOT: Washington; 2009: pp. 1-35.

[35] Tsujino M, Noguchi T, Tamura M, Kanematsu M, Maruyama I, Nagai H. "Study on the Application of Low- Quality Recycled Coarse Aggregate to Concrete Structure by Surface Modification Treatment". 2nd Asian Concrete Federation Conference. 2006, November 20-21; Bali, Indonesia. pp. 36-45.

[36] Spaeth V, Tegguer A D. "Improvement of Recycled Concrete Aggregate Properties by Polymer Treatments". International Journal of Sustainable Built Environment 2013; 2: 143-152.

[37] García-González J, Rodríguez-Robles D, JuanValdés A, Morán-del Pozo J M, Guerra-Romero M I. "Pre-Saturation Technique of the Recycled Aggregates: Solution to the Water Absorption Drawback in the Recycled Concrete Manufacture". Materials 2014; 7: 6224-6236.

[38] Jagadeesh S, Ramesh K V, Ganesh S, Kumar D S S. "Study on Tensile Strength Properties of Recycled Aggregate Concrete with and without Pozzolanic Materials". International Journal of Civil Engineering and Technology 2018; 9(11): 671-679.

[39] Hai-long W, Jun-jie W, Xiao-yan S, Wei-liang J. "Improving Performance of Recycled Aggregate Concrete with Superfine Pozzolanic Powders". Journal of Central South University 2013; 20: 3715-3722.

[40] Kalaiarasu S M, Subramanian K. "Properties of Recycled Aggregate Concrete with Silica Fume". Journal of Applied Sciences 2006; 6(14): 29562958.

[41] Abdul-Rahman M B, Ali A A, Younus A M. "Effecting of Steel Fibers and Fly Ash on the Properties of Concrete". Tikrit Journal of Engineering Sciences 2018; 25 (4): 30-36

[42] Nazarimofrad E, Shiakh F U A, Nili M. "Effects of Steel Fiber and Silica Fume on Impact Behaviour of Recycled Aggregate Concrete". Journal of Sustainable Cement-Based Materials 2017; 6(1): 54-68.

[43] Bhikshm V, Manipal K. "Study on Mechanical Properties of Recycled Aggregate Concrete
Containing Steel Fibers". Asian Journal of Civil Engineering (Building and Housing) 2012; 13(2): 155-164.

[44] Hameed S A. "Mechanical Properties of Fiberous Recycled Aggregate Concrete". Tikrit Journal of Engineering Sciences 2013; 20(4): 42-52.

[45] Sryh L, Forth J. "Experimental Investigation on the Effect of Steel Fibres on the Mechanical Properties of Recycled Aggregate Concrete". Conference Fibre Concrete. 2015 September 1011; Prague, Czech Republic.

[46] Krishna T S. "An Experimental Investigation on Flexural Behavior of Recycle Aggregate Fiber Reinforcement Concrete". International Research Journal of Engineering and Technology 2015; 2(4): 1290-1296.

[47] Pradeep A R, Gowda M I B. "A Case Study on Strength Properties of Partially Replaced Recycled Aggregate and Steel Fibers to A Nominal Concrete". IOSR Journal of Mechanical and Civil Engineering 2016; 13 (3): 52-58.

[48] Chandar S P, Gunasekaran K, Sandeep N S, Manikandaprabhu S. "An Experimental Investigation on Strength Properties of Steel Fibres Along with Recycled Aggregate in Cement Concrete". Rasayan Journal of Chemistry 2017; 10(2): 528-533.

[49] Bhan C, Kaur M. "Strength Characteristics of Recycled Concrete Aggregate with Addition of Steel Fibres". International Journal of Advance Research and Development 2018; 3(11): 10-15.

[50] Sryh L, Forth J. "Effect of Steel Fibres and Recycled Aggregate on Drying Shrinkage and Creep Deformations of Concrete". The 9th International Concrete Conference Environment, Efficiency and Economic Challenges for Concrete. 2016, July 4-6; Dundee, Scotland: University of Dundee.

[51] Ghorpade V G. "Effect of Recycled Coarse Aggregate on Workability and Shear Strength of Fibre Reinforced High Strength Concrete". International Journal of Innovative Research in Science, Engineering and Technology 2013; 2(8): 3377-3383.

[52] Heeralal M, Kumar P R, Rao Y V. "Flexural Fatigue Characteristics of Steel Fiber Reinforced Recycled Aggregate Concrete (SFRRAC)". Architecture and Civil Engineering 2009: 7 (1): 19-33. 